European

Thyroid Journal
Eur Thyroid J 2015;4:14-19

DOI: $10.1159 / 000371740$
Received: September 1, 2014

Accepted after revision: December 22, 2014

Published online: February 19, 2015

\title{
Rapid Bioassay for Detection of Thyroid-Stimulating Antibodies Using Cyclic Adenosine Monophosphate-Gated Calcium Channel and Aequorin
}

\author{
Naohiro Araki ${ }^{a}$ Mitsuru lida ${ }^{a}$ Nobuyuki Amino ${ }^{b}$ Shinji Morita ${ }^{b}$ \\ ${\text { Akane } \text { Ide }^{b} \text { Eijun Nishihara }}^{b}$ Mitsuru Ito ${ }^{b}$ Jun Saito ${ }^{c}$ Tetsuo Nishikawa $^{c}$ \\ Kiyonori Katsuragia ${ }^{a}$ Akira Miyauchib

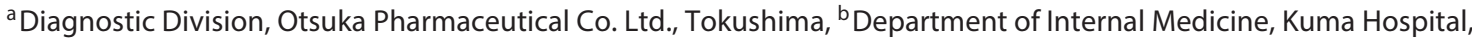 \\ Kobe, and 'Department of Medicine, Yokohama Rosai Hospital, Yokohama, Japan
}

\section{Key Words}

Graves' disease · Antithyroid-stimulating hormone receptor antibodies · Thyroid-stimulating antibodies · Aequorin .

Bioassay

\begin{abstract}
Background: Thyroid-stimulating antibodies (TSAb) are known to be responsible for hyperthyroidism in Graves' disease (GD). The conventional methods to measure TSAb depend on cell-based assays that require cumbersome procedures and a sterilized tissue culture technique. The aim of the present study was to develop a ready-to-use cell-based assay for measuring TSAb activity without requiring sterilized conditions. Methods: We developed a new assay kit using a frozen Chinese hamster ovary cell line expressing the thyroid-stimulating hormone receptor, cyclic adenosine monophosphate (CAMP)-gated calcium channel and aequorin, tentatively named the aequorin TSAb assay. Activated stimulatory G-protein-coupled adenylate cyclase increases intracellular CAMP, which then binds to the cyclic nucleotide-gated calcium channel. Activation of this channel allows $\mathrm{Ca}^{2+}$ to enter the cell, and the influx of $\mathrm{Ca}^{2+}$ can be measured with
\end{abstract}

aequorin, which is quantified by a luminometer. Results can be obtained in only $4 \mathrm{~h}$ without sterilized conditions. TSAb activities were expressed by international units using the NIBSC 08/204 standard. Results: Positive results of aequorin TSAb were obtained in 197 of 199 (98.9\%) of untreated patients with GD. Only 1 of 42 (2.3\%) patients with painless thyroiditis had a weakly positive aequorin TSAb. All 45 patients with subacute thyroiditis and 185 normal subjects showed negative aequorin TSAb. As for chronic thyroiditis, all 52 euthyroid patients showed negative aequorin TSAb, but 8 of 50 (16.0\%) hypothyroid patients had a positive reaction. However, these positive reactions were not induced by serum thyroid-stimulating hormone (TSH) and were thought to be induced by the stimulating activity of anti-TSH receptor immunoglobulins. Conventional porcine TSAb and Elecsys thyroid-stimulating hormone receptor antibodies were positive in 69.3 and $95.5 \%$ of GD, respectively. Conclusion: The aequorin TSAb assay was positive in $98.9 \%$ of GD and was more sensitive than the conventional assay. This assay can be conducted in only $4 \mathrm{~h}$ without sterilized conditions and is practically useful in general clinical laboratories.

(c) 2015 European Thyroid Association Published by S. Karger AG, Basel

\begin{tabular}{ll}
\hline KARGER 125:s & $\begin{array}{l}\text { ( 2015 European Thyroid Association Karger } \\
\text { Published by S. Karger AG, Basel } \\
2235-0640 / 15 / 0041-0014 \$ 39.50 / 0\end{array}$ \\
E-Mail karger@karger.com & $\begin{array}{l}\text { This is an Open Access article licensed under the terms of the } \\
\text { Creative Commons Attribution-NonCommercial 3.0 Un- } \\
\text { ported license (CC BY-NC) (www.karger.com/OA-license), } \\
\text { applicable to the online version of the article only. Distribu- }\end{array}$
\end{tabular}

Nobuyuki Amino, MD

Department of Internal Medicine, Kuma Hospital

8-2-35 Shimoyamate-dori, Chuo-ku

Kobe 650-0011 (Japan)

E-Mail namino@kuma-h.or.jp 


\section{Introduction}

Autoantibodies to the thyroid-stimulating hormone receptor (TSHR) are functionally heterogeneous and bind to the receptor with high affinity [1-3]. Based on their biological activities, they have been classified into either thyroid-stimulating antibodies (TSAb) or thyroidstimulating blocking antibodies (TSBAb). TSAb have been shown to be responsible for hyperthyroidism in Graves' disease (GD), whereas TSBAb occur mainly in patients with atrophic thyroiditis and Hashimoto's thyroiditis [3].

The amount of TSHR antibodies can be measured with competitive binding assays, the so-called thyrotropinbinding inhibitory immunoglobulin/TSHR antibodies (TRAb) assay, using either labeled thyroid-stimulating hormone (TSH) or a monoclonal antibody against the TSHR $[4,5]$. Although these assays are very useful, the binding assays reflect the amount of antibodies in patient serum but cannot discriminate TSAb from TSBAb. The conventional methods to measure TSAb and TSBAb depend on cell-based assays using various cells such as porcine primary cells, human thyroid cells and Fischer rat thyroid cell line-5 (FRTL-5), combined with the measurement of cyclic adenosine monophosphate (cAMP) released from the cells. Furthermore, several research groups have developed stably transformed cell lines with a reporter plasmid containing the firefly luciferase gene under the control of multiple cAMP-responsible elements [6-8]. However, these assays require tissue culture facilities and a lot of time [9], which limit their use outside specialized laboratories.

In order to overcome these limitations, we established a new live-cell bioassay that uses a genetically engineered Chinese hamster ovary cell line expressing human TSHR, cyclic nucleotide-gated calcium channel and aequorin $[10,11]$, tentatively named the aequorin TSAb assay. This assay can be started by simply thawing the frozen cells and does not require tissue culture facilities, which is beneficial for use in general clinical laboratories.

\section{Subjects and Methods}

\section{Subjects}

We examined 199 untreated patients with GD (mean age 39 years, range 8-79 years; 150 female): 42 with thyrotoxic painless thyroiditis (PT; mean age 42 years, range $14-74$ years; 37 female); 45 with thyrotoxic subacute thyroiditis (mean age 44 years, range 27-79 years; 42 female), 102 with chronic thyroiditis (52 euthyroid; mean age 53 years, range 15-79 years; 48 female); 50 with hypothyroidism (mean age 55 years, range 16-94; 40 female) and 185 normal subjects (mean age 41 years, range $13-78$ years; 41 female). The diagnosis of these thyroid diseases was made according to the diagnostic guidelines of the Japan Thyroid Association [12]. Sera were obtained from these patients and control subjects and stored at $-20^{\circ} \mathrm{C}$. Informed consent was obtained from each patient, and institutional approval was obtained from the Kuma Hospital.

\section{Principle and Procedure of the Aequorin TSA $b$ and TSBAb} Assay

The principle of the aequorin assay is to measure intracellular cAMP production by TSHR activation. The Chinese hamster ovary cell line ( $\mathrm{CHO}-\mathrm{K} 1$ cell line) was transfected with a mammalian expression vector containing full-length human TSHR [13], cyclic nucleotide-gated calcium channel [14] and aequorin [15]. TSAb activate the TSHR and then increase intracellular cAMP, leading to the direct activation of the cyclic nucleotide-gated calcium channel. The addition of a calcium-containing buffer results in an intracellular calcium influx which activates the intracellular photoprotein aequorin. The aequorin emits a blue light at relaxation, the intensity of which is correlated with the degree of TSHR activation. The luminescence of aequorin emitted by calcium addition is quantified by a luminometer.

Serum $(25 \mu \mathrm{l})$ was diluted with $100 \mu \mathrm{l}$ of buffer 1 by vortexing. The frozen cells stored at $-80^{\circ} \mathrm{C}\left(3 \times 10^{6} \mathrm{cells} / \mathrm{ml}\right)$ were thawed in a water bath at $37^{\circ} \mathrm{C}$ for $2 \mathrm{~min}$, transferred to $10 \mathrm{ml}$ of buffer 1 and then centrifuged for $5 \mathrm{~min}$ at 1,000 rpm. The cell pellets were suspended in $12 \mathrm{ml}$ of buffer 2 and $25 \mu$ of luminescence substrate Viviren $^{\mathrm{TM}}$ (Promega, Madison, Wisc., USA) by gentle pipetting. The neutralizing antibody against human TSH (hTSH) was included in buffer 2 . The diluted sample (1:5) was added to a 96-well white plate $(25 \mu \mathrm{l}$ duplicate) followed by $100 \mu \mathrm{l}$ of cell suspension and incubated for $4 \mathrm{~h}$ at $25^{\circ} \mathrm{C}$. The light luminescence of each well was recorded for $7 \mathrm{~s}$ by adding $100 \mu \mathrm{l}$ of detection buffer containing $100 \mathrm{~mm}$ calcium chloride using an injector equipped with a luminometer (Victor/Arvo-SX; PerkinElmer, Waltham, Mass., USA). The activities of aequorin TSAb were calibrated using the international standard NIBSC 08/204 and expressed as milli-international units per liter. A calibration curve was run on every plate. The data could be calculated either with a point-to-point calibration curve or a 4-parameter logistic nonlinear regression analysis. The porcine TSAb assay was performed using a Yamasa kit (Yamasa Corporation, Choshi, Japan), and TSAb activity was expressed as the percentage of cAMP production compared to that of the normal control [16]. In order to examine the effect of hTSH on the assay, various concentrations of hTSH (NIBSC 80/558) were added to a pooled normal serum, and the aequorin TSAb assay, porcine TSAb assay and Elecsys TRAb assay were performed. For measuring TSBAb activity, the procedure of aequorin TSAb assay was slightly modified: $25 \mu \mathrm{l}$ of $500 \mu \mathrm{IU} / \mathrm{ml}$ bovine TSH and the diluted sample were serially added to a 96 -well white plate followed by $100 \mu \mathrm{l}$ of cell suspension. The values were expressed as percentage inhibition of luminescence compared to that of the normal control.

\section{Thyroid Function and Antibodies}

Serum TSH, free thyroxine and free triiodothyronine concentrations were measured using chemiluminescent immunoassays (Architect TSH, Architect free thyroxine and Architect free triio- 
Table 1. Intra-assay and interassay variation in aequorin TSAb assay

\begin{tabular}{lccc}
\hline Serum sample & High & Middle & Low \\
\hline Intra-assay & & & \\
$\mathrm{n}$ & 12 & 12 & 12 \\
Average, mIU/1 & 512.6 & 380.2 & 116.3 \\
$\mathrm{SD}$ & 43.3 & 19.7 & 7.3 \\
Coefficient of variation, \% & 8.4 & 5.2 & 6.3 \\
\hline Interassay & & & \\
$\mathrm{n}$ & 12 & 12 & 12 \\
Average, mIU/1 & 537.0 & 386.1 & 117.3 \\
SD & 63.2 & 28.5 & 9.1 \\
Coefficient of variation, \% & 11.8 & 7.4 & 7.7 \\
\hline
\end{tabular}

dothyronine, respectively; Abbott Japan Co., Tokyo, Japan). Normal ranges are $0.3-5.0 \mathrm{mIU} / \mathrm{l}$ for TSH, 9.0-20.3 pmol/1 for free thyroxine and 2.6-5.7 pmol/l for free triiodothyronine. Serum levels of antithyroglobulin antibody, antithyroid peroxidase antibody, and anti-TRAb were measured using an electrochemiluminescence immunoassay (ECLusys 2010; Roche Diagnostics Japan Co., Tokyo, Japan; normal range: $<40 \mathrm{kIU} / \mathrm{l}$ for antithyroglobulin antibody, $<28 \mathrm{kIU} / \mathrm{l}$ for antithyroid peroxidase antibody and $<2.0$ IU/l for TRAb), as previously reported [17].

\section{Statistical Analysis}

Various parameters were compared among the thyroid diseases by the Mann-Whitney test. The relationship between aequorin TSAb and porcine TSAb or Elecsys TRAb was examined by linear correlation analysis. Differences were considered to be significant at $\mathrm{p}<0.05$.

\section{Results}

The value of aequorin TSAb activities was multiplied by the dilution factor and then expressed as milli-international units per liter. The value was calibrated by the international standard NIBSC 08/204. Increased light output was detectable from 35 to $750 \mathrm{mIU} / \mathrm{l}$. The detection limit of the aequorin assay was $18 \mathrm{mIU} / \mathrm{l}$ (blank +3 $\mathrm{SD}, \mathrm{n}=12$ ). Intra- or interassay precision with high, middle and low control serum giving coefficients of variation were acceptable for routine use (table 1). Interassay coefficients of variation of high, middle and low serum using 3 different lots were $14.6,7.0$ and $7.4 \%$, respectively. As for the interference of other hormones and pigments, high concentrations of human chorionic gonadotropin spiked in healthy serum up to $1,250,000 \mathrm{IU} / 1$, human follicle-stimulating hormone up to $100,000 \mathrm{IU} / \mathrm{l}$, human thyroxine-binding globulin up to $0.925 \mu \mathrm{mol} / \mathrm{l}$, human prolactin up to $4.3 \mu \mathrm{mol} / \mathrm{l}$, bilirubin $\mathrm{F}$ up to $3,230 \mu \mathrm{mol} / / \mathrm{l}$, bilirubin C up to 3,560 $\mu \mathrm{mol} / \mathrm{l}$, hemolytic hemoglobin up to $0.31 \mathrm{mmol} / \mathrm{l}$ and chyle up to 9,870 formazine turbidity units had no effect on the aequorin TSAb assay.

The receiver operating characteristic analysis was performed in 199 patients with untreated GD and with 185 healthy individuals. The optimal cutoff limit was calculated at $35 \mathrm{mIU} / 1$ (sensitivity $98.0 \%$, specificity $100 \%)$. The TSBAb activity was measured for the 185 normal subjects and the 50 hypothyroid patients. The TSBAb activity of normal subjects ranged from -14.0 to $9.0 \%$, and the average was $-2.1 \%$. The cutoff values of the TSBAb activity were estimated to be $5.8 \%$ (average $+2 \mathrm{SD})$.

The results of aequorin TSAb in various thyroid diseases are summarized in table 2 and compared with porcine TSAb and Elecsys TRAb. Positive results of aequorin TSAb were obtained in 197 of 199 (98\%) of untreated patients with GD. Only 1 of $42(2.3 \%)$ patients with PT had a weakly positive aequorin TSAb. All 45 patients with subacute thyroiditis and 185 normal subjects showed negative aequorin TSAb. As for chronic thyroiditis, all 52 euthyroid patients showed negative aequorin TSAb, but 8 of 50 (16.0\%) hypothyroid patients had a positive reaction. By contrast, conventional porcine TSAb and Elecsys TRAb were positive in 69.3 and $95.5 \%$ of GD, respectively. Individual data of aequorin TSAb are shown in figure 1.

The results of patients who showed discrepant results for the positive and negative classification between aequorin TSAb and Elecsys TRAb in GD and $\mathrm{PT}$ are shown in online supplementary table 1 (for all online suppl. material, see www.karger.com/ doi/10.1159/000371740). All of these discrepant GD patients had mild or moderate hyperthyroidism, and aequorin TSAb possibly detected low antibody activity efficiently. In 1 PT patient, aequorin TSAb disappeared rapidly. The results of hypothyroid patients who showed discrepant results among aequorin TSAb, porcine TSAb and Elecsys TRAb are shown in online supplementary table 2. Although all hypothyroid patients showed positive aequorin TSAb without anti-hTSH, only 8 patients showed positive aequorin TSAb with anti-hTSH. Our aequorin TSAb assay does not respond to coexisting TSH, since hTSH was neutralized with additional antihTSH antibodies in the buffer, as shown in table 3. Aequorin TSAb-positive reactions are thought to be induced by immunoglobulins of TRAb, since aequorin TSAb activities significantly correlated with Elecsys TRAb activities $(\mathrm{r}=0.652, \mathrm{p}<0.05)$ but not with TSH levels. Four of these hypothyroid patients with positive TSAb also had positive TSBAb.
Araki/Iida/Amino/Morita/Ide/Nishihara/ Ito/Saito/Nishikawa/Katsuragi/Miyauchi 
Fig. 1. Individual values of aequorin TSAb in untreated GD $(\mathrm{n}=195)$, PT $(\mathrm{n}=44)$, subacute thyroiditis $(\mathrm{n}=45)$, chronic thyroiditis (euthyroid $\mathrm{n}=52$, hypothyroid $\mathrm{n}=$ $50)$ and normal subjects $(\mathrm{n}=185)$.

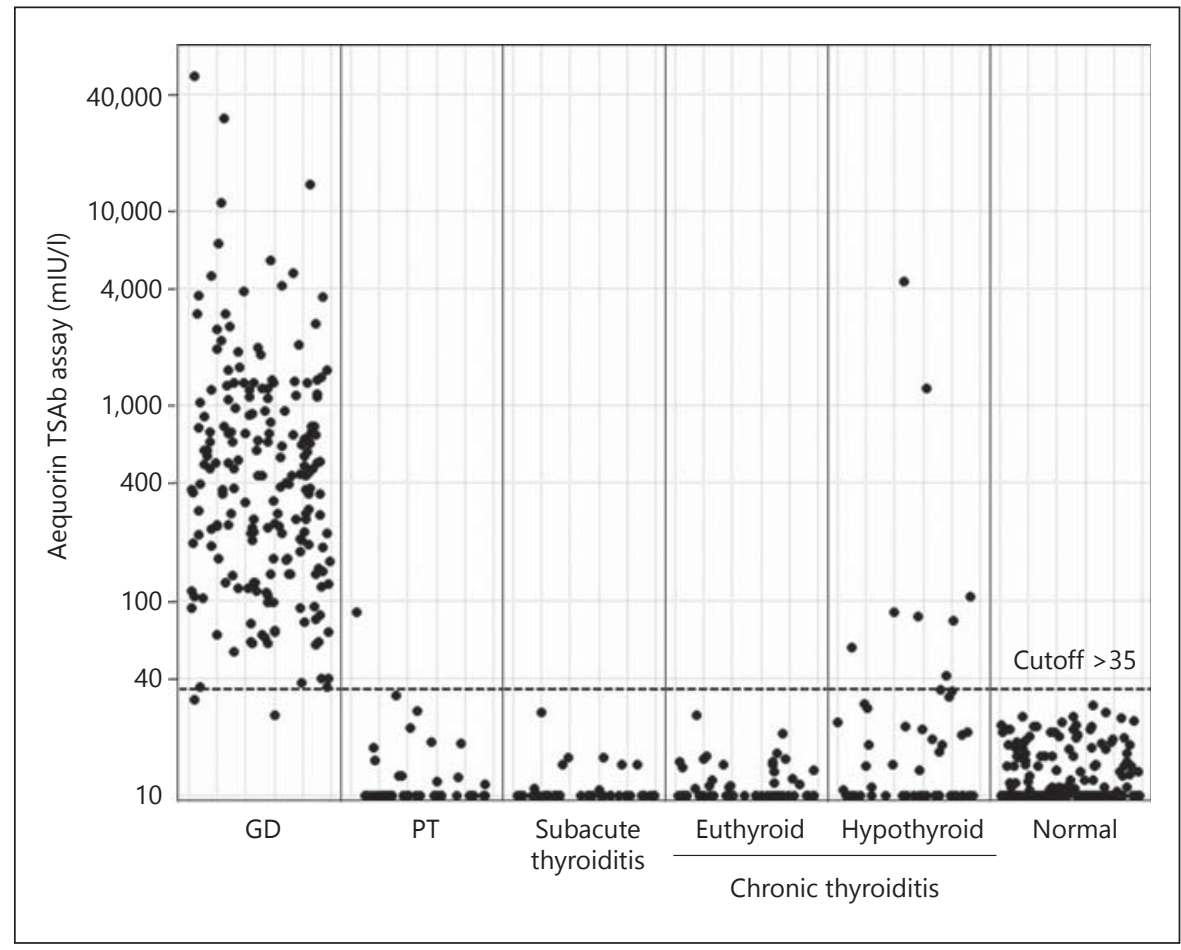

Table 2. Comparison of aequorin TSAb assay with porcine TSAb or Elecsys TRAb

\begin{tabular}{|c|c|c|c|c|c|c|c|}
\hline \multirow[t]{2}{*}{ Diagnosis } & \multirow[t]{2}{*}{$\mathrm{n}$} & \multicolumn{2}{|c|}{ Aequorin TSAb } & \multicolumn{2}{|c|}{ Porcine TSAb } & \multicolumn{2}{|c|}{ Elecsys TRAb } \\
\hline & & positive & negative & positive & negative & positive & negative \\
\hline Untreated GD & 199 & 197 & 2 & 138 & 61 & 190 & 9 \\
\hline PT & 42 & 1 & 41 & 0 & 42 & 0 & 42 \\
\hline Subacute thyroiditis & 45 & 0 & 45 & 0 & 45 & 0 & 45 \\
\hline \multicolumn{8}{|l|}{ Chronic thyroiditis } \\
\hline Euthyroid & 52 & 0 & 52 & 0 & 52 & 0 & 52 \\
\hline Hypothyroid & 50 & 8 & 42 & 14 & 36 & 8 & 42 \\
\hline Normal & 185 & 0 & 185 & 0 & 185 & 0 & 185 \\
\hline
\end{tabular}

Overall sensitivity to detecting GD was $98.9 \%$ in the aequorin assay, $69.3 \%$ in the porcine TSAb assay and $95.4 \%$ in the Elecsys TRAb assay, respectively. There were significant correlations between aequorin TSAb and porcine TSAb or Elecsys TRAb, as shown in figure 2.

\section{Discussion}

In this study, we developed a sensitive and rapid TSAb bioassay. All of the previous bioassays for TSAb required cell culture under sterilized conditions and took more than $20 \mathrm{~h}$ [9]. The aequorin TSAb assay only takes $4 \mathrm{~h}$ and does not require a sterilized culture. Our aequorin TSAb assay is the first bioassay using the international standard NIBSC 08/204, and TSAb activities are expressed as milliinternational units per liter. Previous TSAb bioassays expressed the results as the relative percent value compared to normal serum. Very recently, Giuliani et al. [18] used arbitrary units for TSAb activities, but the basis is the same as the percent increase and is not internationally standardized. The main problem of using these relative values is that they tend to vary among cell lots or incubation conditions, which makes it difficult to use these bio- 


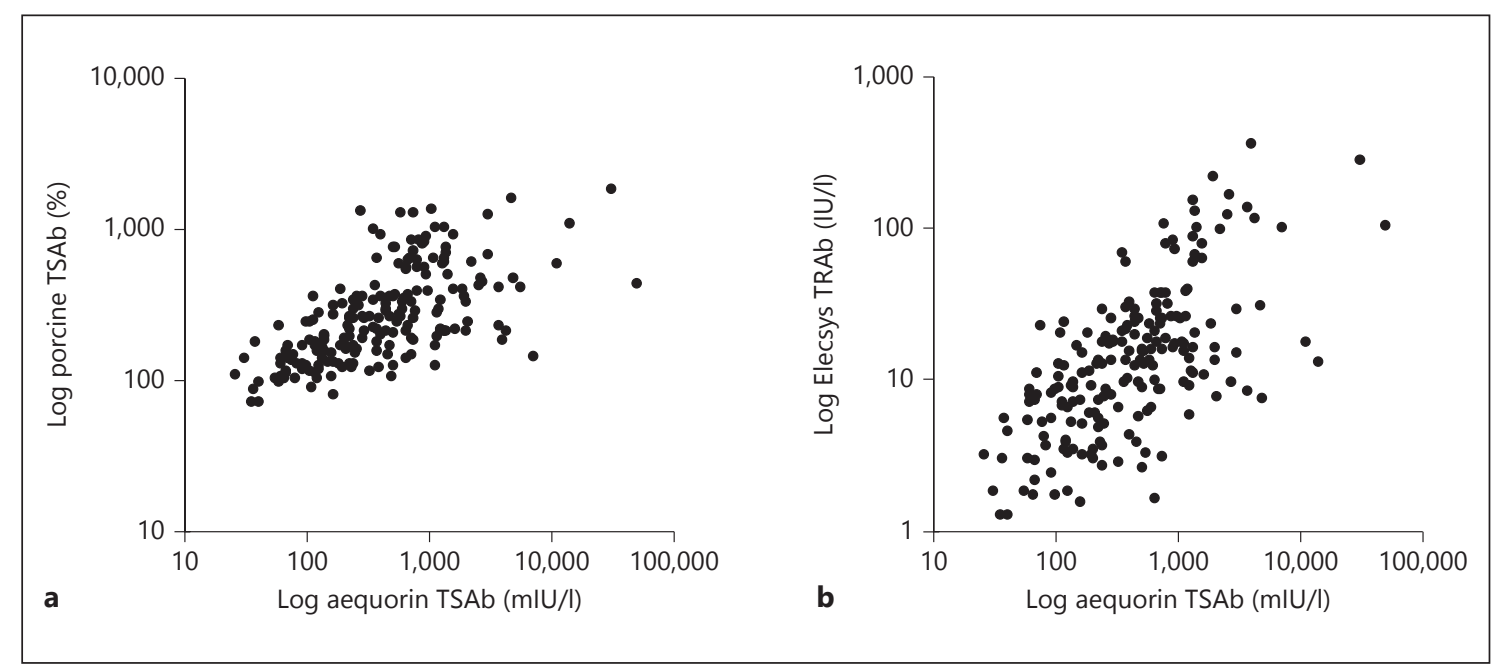

Fig. 2. Correlations between aequorin TSAb values and porcine TSAb (a; $r=0.296, p<0.001)$ or Elecsys TRAb (b; $r=0.396, p<0.001)$ in GD $(n=195)$.

Table 3. Effect of hTSH in the serum

\begin{tabular}{llll}
\hline & $\begin{array}{l}\text { Aequorin TSAb } \\
(<35), \mathrm{mIU} / \mathrm{l}\end{array}$ & $\begin{array}{l}\text { Porcine TSAb } \\
(<180), \%\end{array}$ & $\begin{array}{l}\text { Elecsys TRAb } \\
(<2.0), \mathrm{IU} / \mathrm{l}\end{array}$ \\
\hline Normal serum & $<35$ & $141.5 \pm 17.7$ & $<2.0$ \\
$+10 \mathrm{mIU} / \mathrm{l} \mathrm{hTSH}$ & $<35$ & $248.0 \pm 10.5$ & $<2.0$ \\
$+100 \mathrm{mIU} / \mathrm{l} \mathrm{hTSH}$ & $<35$ & $320.3 \pm 27.1$ & $<2.0$ \\
$+500 \mathrm{mIU} / \mathrm{l} \mathrm{hTSH}$ & $<35$ & $495.7 \pm 113.8$ & $<2.0$ \\
\hline
\end{tabular}

assays for monitoring the disease prognosis and comparing results among different laboratories throughout the world. We previously clarified that the product of standardized TRAb and TSAb activities was a most useful predictor for neonatal thyrotoxicosis $[19,20]$. Considering this, it is very important to use the standardized activities of TSAb.

In untreated GD, aequorin TSAb was detected in $98.9 \%$ of patients, and porcine TSAb was positive in $69.3 \%$ of patients, indicating that the aequorin assay had higher sensitivity than the porcine TSAb assay. A similar positive reaction (95.5\%) was observed in the Elecsys TRAb assay. In 9 patients with untreated GD, who showed negative or borderline Elecsys TRAb, 8 had clearly positive aequorin TSAb, suggesting that aequorin TSAb is more sensitive than Elecsys TRAb for the detection of GD. Interestingly, in patients with chronic thyroiditis, 8 of $50(16.0 \%)$ hypothyroid patients, but no euthyroid ones, showed positive aequorin TSAb. The aequorin
TSAb assay used a neutralizing antibody specific to hTSH in the buffer, and aequorin TSAb activities were not correlated with serum TSH. Therefore, the aequorin TSAb reaction in hypothyroid patients is not induced by serum $\mathrm{TSH}$. These aequorin TSAb activities significantly correlated with TRAb activities, strongly suggesting that positive aequorin TSAb in hypothyroid patients is induced by anti-TSHR immunoglobulins. Considering these points, some hypothyroid patients seemed to have a stimulating antibody just like hypothyroid GD, while others seemed to have weak partial agonist activity caused by the coexistence of TSBAb.

In conclusion, the newly developed aequorin TSAb assay provides a very sensitive and useful method for measuring TSAb activity in both GD and hypothyroid patients. The aequorin assay can be conducted in only $4 \mathrm{~h}$ without sterilized conditions and cell culture techniques, which is ideal for its routine use in general clinical laboratories.

\section{Acknowledgments}

We wish to acknowledge Drs. N. Nakayama, S. Takahashi, H. Yamada, K. Sudo and O. Kosaka for their helpful advice during this work and Dr. C. Yoshimura's technical assistance.

\section{Disclosure Statement}

The authors declare that no competing financial interests exist.
Araki/Iida/Amino/Morita/Ide/Nishihara/ Ito/Saito/Nishikawa/Katsuragi/Miyauchi 


\section{References}

-1 Watanabe Y, Tahara K, Hirai A, Tada H, Kohn LD, Amino N: Subtypes of anti-TSH receptor antibodies classified by various assays using CHO cells expressing wild-type or chimeric human TSH receptor. Thyroid 1997;7: 13-19.

-2 Morgenthaler NG, Ho SC, Minich WB: Stimulating and blocking thyroid-stimulating hormone (TSH) receptor autoantibodies from patients with Graves' disease and autoimmune hypothyroidism have very similar concentration, TSH receptor affinity, and binding sites. J Clin Endocrinol Metab 2007; 92:1058-1065.

-3 McLachlan SM, Rapoport B: Thyrotropinblocking autoantibodies and thyroid-stimulating autoantibodies: potential mechanisms involved in the pendulum swinging from hypothyroidism to hyperthyroidism or vice versa. Thyroid 2013;23:14-24.

-4 Yoshimura Noh J, Miyazaki N, Ito K, Takeda K, Hiramatsu S, Morita S, Miyauchi A, Murakami $T$, Inomata $K$, Noguchi $S$, Satoh $T$, Amino N: Evaluation of a new rapid and fully automated electrochemiluminescence immunoassay for thyrotropin receptor autoantibodies. Thyroid 2008;18:1157-1164.

$\checkmark 5$ Smith BR, Bolton J, Young S, Collyer A, Weeden A, Bradbury J, Weightman D, Perros P, Sanders J, Furmaniak J: A new assay for thyrotropin receptor autoantibodies. Thyroid 2004; 14:830-835.

6 Evans C, Morgenthaler NG, Lee S, Llewellyn $\mathrm{DH}$, Clifton-Bligh R, John R, Lazarus JH, Chatterjee VK, Ludgate M: Development of a luminescent bioassay for thyroid stimulating antibodies. J Clin Endocrinol Metab 1999;84: 374-377.
7 Watson PF, Ajjan RA, Phipps J, Metcalfe R, Weetman AP: A new chemiluminescent assay for the rapid detection of thyroid stimulating antibodies in Graves' disease. Clin Endocrinol (Oxf) 1998;49:577-581.

8 Lytton SD, Ponto KA, Kanitz M, Matheis N, Kohn LD, Kahaly GJ: A novel thyroid stimulating immunoglobulin bioassay is a functional indicator of activity and severity of Graves' orbitopathy. J Clin Endocrinol Metab 2010;95:2123-2131.

$>9$ Lytton SD, Kahaly GJ: Bioassays for TSH-receptor autoantibodies: an update. Autoimmun Rev 2010;10:116-122.

$>10$ Dupriez VJ, Maes K, Le Poul E, Burgeon E, Detheux M: Aequorin-based functional assays for G-protein-coupled receptors, ion channels, and tyrosine kinase receptors. Receptors Channels 2002;8:319-330.

-11 Mithöfer A, Mazars C: Aequorin-based measurements of intracellular $\mathrm{Ca}^{2+}$-signatures in plant cells. Biol Proced Online 2002;4:105118.

12 Japan Thyroid Association: Guidelines for the diagnosis of thyroid disease. 2010. http// www.japanthyroid.jp/doctor/guideline/ english.html.

13 Nagayama Y, Kaufman KD, Seto P, Rapoport $\mathrm{B}$ : Molecular cloning, sequence and functional expression of the cDNA for the human thyrotropin receptor. Biochem Biophys Res Commun 1989;165:1184-1190.

14 Ruiz ML, London B, Nadal-Ginard B: Cloning and characterization of an olfactory cyclic nucleotide-gated channel expressed in mouse heart. J Mol Cell Cardiol 1996;28:1453-1461.
15 Rizzuto R, Brini M, Pozzan T: Intracellular targeting of the photoprotein aequorin: a new approach for measuring, in living cells, $\mathrm{Ca}^{2+}$ concentrations in defined cellular compartments. Cytotechnology 1993;11:S44S46.

16 Kamijo K, Nagata A, Sato Y: Clinical significance of a sensitive assay for thyroid-stimulating antibodies in Graves' disease using polyethylene glycol at high concentrations and porcine thyroid cells. Endocr J 1999;46: 397-403.

17 Ide A, Amino N, Kang S, Yoshioka W, Kudo T, Nishihara E, Ito M, Nakamura H, Miyauchi A: Differentiation of postpartum Graves' thyrotoxicosis from postpartum destructive thyrotoxicosis using antithyrotropin receptor antibodies and thyroid blood flow. Thyroid 2014;24:1027-1031.

18 Giuliani C, Cerrone D, Harii N, Thornton M, Kohn LD, Dagia NM, Fiore E, Bucci I, Chamblin T, Vitti P, Monaco F, Napolitano G: A TSHr-LH/CGr chimera that measures functional TSAb in Graves' disease. J Clin Endocrinol Metab 2012;97:E1106-E1115.

19 Amino N, Watanabe Y, Tamaki H, Iwatani Y, Miyai K: In-vitro conversion of blocking type anti-TSH receptor antibody to the stimulating type by anti-human IgG antibodies. Clin Endocrinol (Oxf) 1987;27:615-624.

$\checkmark 20$ Tamaki H, Amino N, Iwatani Y, Tachi J, Kimura M, Mitsuda N, Ichihara K, Tanizawa O, Miyai K: Evaluation of TSH receptor antibody by 'natural in vivo human assay' in neonates born to mothers with Graves' disease. Clin Endocrinol (Oxf) 1989;30:493503. 